\title{
グラウスールを対象とした熱，水分因子による長期性状変化に関する研究 INFLUENCE OF TEMPERATURE AND MOISTURE ON AGING OF GLASS WOOL
}

\author{
立松宏一*，廣田誠一**，鈴木大隆***，谷口円*** \\ 布井洋二****, 鵜澤孝夫*****
Koichi TATEMATSU, Tomohito HIROTA, Hirotaka SUZUKI, Madoka TANIGUCHI, Yoji NUNOI and Takao UZAWA

\begin{abstract}
The promotion of the long-term use of high-quality building stock is a very important subject. To accomplish this, it is necessary to understand the long-term changes in the properties of insulation materials.

In this research, we verified the durability of glass wool by conducting a survey of the changes in this insulation with long-term use and by performing an acceleration test. As a result, it was found that under high-temperature and high-humidity conditions, the strength of the glass fiber decreases, and the binder deteriorates. However, the thermal conductivity did not increase.

We then developed a piercing test to evaluate the aging of glass wool. Finally, we attempted to predict the aging by applying a life prediction model to the accelerated test.
\end{abstract}

Keywords: Fiber Insulation, Durability, Long-term Performance, Piercing Test, Accelerated Test 繊維系断熱材，而久性，経年変化，促進試験，突き刺し試験

\section{1 はじめに}

良質な建築ストックの形成を図り、その長期利用の促進を図るこ とは重要な課題である。そのためには、各種建材の長期的な性状の 変化を把握することが必要である。

断熱材に関しては、近年長期断熱性能評価に関する標準化調査(以 下「標準化調查」という(1)が行われ、近藤ら 2) 4)により成果が報告 されている。その中で、特に発泡プラスチック系の断熱材について は、ガス置換により熱伝導率の経年変化を起こす場合があるため詳 細な検討が行われ、長期断熱性能に関する知見が蓄積されつつある。

一方、繊維系断熱材については、振動と水分(水蒸気や液水)を性 能変化要因としていくつかの検証が行われている状況にとどまって いる。振動に関しては、壁と天井に施工されたグラスウールとロッ クウールを対象に、断熱材の寸法と断熱性能の変化に関する実験が 行われ、天井の吹込み施工の場合に、振動による沈降により断熱材 厚さや熱抵抗の変化が生ずることが確認されている ${ }^{3)}$ 。この沈降現 象については、設計厚さよりも厚く施工することを標準仕様とする ことで従来から対策が行われている5)。また沈降試験の方法は ISO 18393 において策定が進められている ${ }^{6)}$ 。水分と性能変化の関係に ついては、断熱材の含水率が増加するにしたがって熱伝導率が直線 的に増加することや、グラスウールでは含水により厚さが減少し、 乾燥後においても含水前の厚さに完全に戻らないことが報告されて
(る 4)。これらの検証結果をもとに繊維系断熱材の長期性能評価方 法の考え方として、交通などによる振動の影響で沈降著しい場合や、 水分による影響が著しいなど特別の場合を除き、経年変化は考慮せ ず、湿度による年間周期変動を考慮することが提案されている 1)。

また、硝子繊維協会では竣工後 7 年から 26 年を経過した住宅 6 棟を対象に、長期経過後のグラスウールの実態調查を行い、適切に 施工された住宅では、壁の中のグラスウールはほとんどが施工当時 と変わらない状態を保っており、熱性能も施工当時の規格值を満足 していることを確認している7)

しかしながら、ガラス繊維の固定に用いられている樹脂バインダ 一が水分によって劣化することがあるとの指摘も一方でなされてお り、例えば JASS24(解説)には「内部結露や雨水の浸入が生じた場 合は、フェルト状断熱材では繊維を結合しているバインダーの劣化 などによってへたりを生じ、ずり落ちる場合もある」5)との記載が ある。また、露出した繊維系断熱材が空調機の長時間の気流により 飛散した事例や 8)、築 30 年経過した住宅のグラスウールを充填した 外壁で断熱性能の低下が見られた事例 9)が報告されている。

標準化調查においても、断熱材メーカー各社に対するヒアリング 調査により、熱や水分はグラスウールの要求性能に対して関係がな いと整理されているが、その根拠となる技術資料やデータはないこ とが明記されている3)。

\footnotetext{
本論文は，参考文献17)の内容に新たな試験結果と考察を加えて加筆し，まとめたものである。

* 北海道立総合研究機構北方建築総合研究所 工修

**北海道立総合研究機構北方建築総合研究所

*** 北海道立総合研究機構北方建築総合研究所 博士 (工学)

**** 旭ファイバーグラス株

$* * * * *$ 硝子繊維協会

Hokkaido Research Organization Northern Regional Building Research Institute, M. Eng.

Hokkaido Research Organization Northern Regional Building Research Institute

Hokkaido Research Organization Northern Regional Building Research Institute, Dr. Eng.

ASAHI FIBER GLASS Co., Ltd.

Glass Fiber Association of Japan
} 
断熱材の長期性能評価に対する要求が高まる中、䋊維系断熱材に ついても経年変化とその要因に関寸る検証が求められている。そこ で本研究は、促進試験および長期使用した断熱材の実態調查により、 グラスウールの長期性状変化に関する検証を行うことを目的とする。

まず、温度および湿度を加速因子とする促進試験を行い、グラス ウールに生じる変化を把握する。次に、現地採取調查を行い、促進 試験による性状変化と比較する。さらに、本研究における性状変化 の検証方法として、新たな試験を提案する。最後に、促進試験に寿 命予測モデルを適用し、経年変化の予測を試みる。

\section{2 研究対象と劣化要因、要求性能の整理}

\section{1 対象とするグラスウール}

グラスウールはガラスを溶融して細く繊維状にし、バインダーを 混ぜて固めた材料である。ガラスは、一般にホウケイ酸ガラスが多 く使われている。また、近年はリサイクルカレットが原料として多 量に使用されている。バインダーはガラス繊維どうしを接着するた めのフェノール樹脂を主成分とする結合剤である。グラスウールの 形状による分類としては、フェルト状、ボード状およびばら状(吹込 み用)の製品があるが、本研究では、住宅に最も多く用いられている フェルト状の製品を主な対象とする。

フェルト状およびボード状の製品には、繊維径が $7 \sim 8 \mu \mathrm{m}$ の「通 常グラスウール」と $4 \sim 5 \mu \mathrm{m}$ の「高性能グラスウール」がある。促 進試験に用いるグラスウールは、寒冷地の住宅に多く使用されてい る高性能グラスウール $16 \mathrm{~K}$ 相当(以下「HG16K」という)を主とす る。

\section{2 劣化要因と要求性能}

標準化調查では、断熱材の要求性能として「断熱性能」「防湿性能」 「気密性能」「形状安定性」を挙げている。繊維系断熱材の場合、防 湿性能と気密性能は別途防湿材や気密材により確保すべき性能であ るため、本研究では断熱性能と形状安定性を考慮する。

また、標準化調査でグラスウールに関係があるとされている性能 変化要因は、「紫外線」「振動」(吹込夕用のみ)「微生物・昆虫／小 動物」「薬品・溶剂」である。このうち、紫外線は通常躯体内では問 題にならず、振動については前述のとおり一定の知見が得られてい る。微生物・昆虫/小動物、薬品・溶剂ついては、実態調查での問 題把握にとどめることとする。

一方、前述のとおり熱や水分との関係については十分な知見がな い。そこで、予備実験として、常用環境よりも高温、高湿の環境に
グラスウールを置いて 20 日間養生したところ、写真 1 のように温 度 $50^{\circ} \mathrm{C}$ 、水蒸気飽和の条件で厚さ方向(繊維の向きに対して概ね垂 直方向)に膨張が生じた。また、同条件において赤色のバインダーの 顕著な退色が観察された。一方、温度 $50^{\circ} \mathrm{C}$ で加湿を行わなかった場 合(dry)は外観上の変化が確認できなかった。温度 $50^{\circ} \mathrm{C}$ の水中に浸 した場合は、水が黄褐色に変色したが、グラスウールを取り出して 乾燥させるとほぼ元通りに復元した。化学反応は温度に依存するた め、高温で短期的に生じる変化は、長期的には常温でも生じる可能 性がある。そこで本研究では、熱、水分によるグラスウールへの影 響について検証することに主眼を置く。

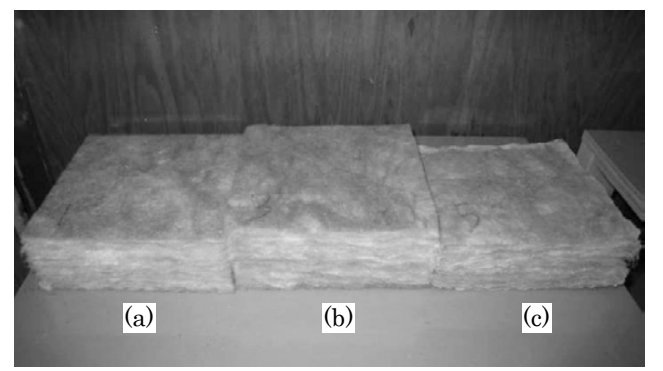

20 日間養生後乾燥させた状態

試験体：D 社 HG16K $300 \times 300 \times 50(\mathrm{~mm})$ 養生条件：(a) $50^{\circ} \mathrm{Cdry}$ 、(b) $50^{\circ} \mathrm{C}$ 水蒸気飽和、(c) $50^{\circ} \mathrm{C}$ 水中

写真 1 予備実験における試験体の変化

\section{3 温湿度促進試験によってグラスウールに生じる変化の把握 3.1 試験の目的と方法}

予備実験により、高温高湿環境でグラスウールに変化が生ずるこ とを確認できたことから、以下では温度および相対湿度を加速因子 とした促進試験を行い、具体的な性状の変化を把握する。

試験項目の一覧を表 1 に示す。まず、予備実験で確認されたグラ スウールの膨張について定量的な把握を行うため、厚さを継続的に 測定する。温度は $50^{\circ} \mathrm{C}$ 一定、湿度は加湿なし、相対湿度 $50 \% 、 95 \%$ (以 下それぞれ「50\%RH」「95\%RH」と記す)の 3 条件とする。

次に、高温高湿条件下におけるグラスウールの変化が断熱性能に 及ぼす影響を把握するため、高温高湿養生による熱伝導率の変化を 測定する。

さらに、グラスウールの構成要素である、バインダーとガラス繊 維それぞれ単体を対象とし、高温高湿養生により両者に変化が生じ

\section{表 1 測定項目}

\begin{tabular}{|c|c|c|c|c|c|c|c|}
\hline 実験項目 & 目的 & 試験体の種類 & メーカー & $\begin{array}{c}\text { 試験体のサイズ } \\
{[\mathrm{mm}]} \\
\end{array}$ & $\begin{array}{l}\text { サンプ } \\
\text { ル数 }\end{array}$ & 養生条件 & 測定方法 \\
\hline $\begin{array}{l}\text { (1)厚さの変化の } \\
\text { 測定 }\end{array}$ & $\begin{array}{l}\text { 相対湿度とグラスウー } \\
\text { ルに生じる膨張の関 } \\
\text { 係の把握 }\end{array}$ & HG16K 50mm厚 & $\mathrm{D}$ & $300 \times 300 \times 50$ & 3 & $\begin{array}{l}\text { (a) } 50^{\circ} \mathrm{Cdry} \\
\text { (b) } 50^{\circ} \mathrm{C} 50 \% \mathrm{RH} \\
\text { (c) } 50^{\circ} \mathrm{C} 95 \% \mathrm{RH}\end{array}$ & $\begin{array}{l}\cdot \text { JIS A952 } 1^{10)} \text { の厚さの測定手順」によ } \\
\text { 测定時に } 150 \mathrm{~mm} \text { 角で質量が } 100 \mathrm{~g} \text { の加 } \\
\text { 重板を載せる。針径は } 0.3 \mathrm{~mm} 、 \text { 測定箇 } \\
\text { 所は中央部のみ } 1 \text { か所とする。 }\end{array}$ \\
\hline (2)熱伝導率測定 & \begin{tabular}{|l} 
高温、高湿環境が断 \\
熱性能に及ぼす影響 \\
の把握
\end{tabular} & HG16K 50mm厚 & $\mathrm{D}$ & $300 \times 300 \times 50$ & 3 & $50^{\circ} \mathrm{C} 95 \% \mathrm{RH}($ 乾燥後測定) &  \\
\hline $\begin{array}{l}\text { (3)バインダーの熱 } \\
\text { 分析 }\end{array}$ & $\begin{array}{l}\text { 高温、高湿環境がバ } \\
\text { インダーに及ぼす影 } \\
\text { 響の把握 }\end{array}$ & $\begin{array}{l}\text { バインダー(グラス } \\
\text { ウールの製造工程と } \\
\text { 同じ温度履歴となる } \\
\text { よう処理したもの) }\end{array}$ & $\mathrm{D}$ & - & - & \begin{tabular}{|l|} 
(a) 常温保管 \\
(b) $50^{\circ} \mathrm{C} 95 \% \mathrm{RH}(27$ 日間) \\
(c) オートクレーブ(10時間、 $108^{\circ} \mathrm{C} 、$ \\
ゲージ圧 $37 \mathrm{kPa}$ 程度で加水)
\end{tabular} & $\begin{array}{l}\text {-示差走査熱量測定(DSC) } \\
\left(\begin{array}{l}\text { 窒素雾囲気下で昇温速度を } 10^{\circ} \mathrm{C} / \mathrm{min} \\
\text { とする。 }\end{array}\right)\end{array}$ \\
\hline $\begin{array}{l}\text { (4)ガラス繊維の表 } \\
\text { 面元素分析 }\end{array}$ & \begin{tabular}{|l|} 
高温、高湿環境がガラ \\
ス繊維に及ぼす影響 \\
の把握
\end{tabular} & $\begin{array}{l}\text { バインダーが付着し } \\
\text { ていないグラスウー } \\
\text { ル }\end{array}$ & $\mathrm{A}, \mathrm{B}, \mathrm{C}$ & - & - & $50^{\circ} \mathrm{C} 95 \% \mathrm{RH}$ & $\begin{array}{l}\text { ·走査型電子顕微鏡(SEM)による観察 } \\
\text { ・エネルギー分散型X線分析(SEM-EDX) }\end{array}$ \\
\hline
\end{tabular}






(a) $50^{\circ} \mathrm{Cdry}$

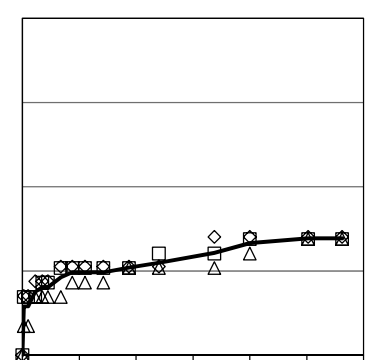

$\begin{array}{llllll}40 & 80 & 120 & 160 & 200 & 240\end{array}$ 経過日数

(b) $50^{\circ} \mathrm{C} 50 \% \mathrm{RH}$

図 1 厚さの変化

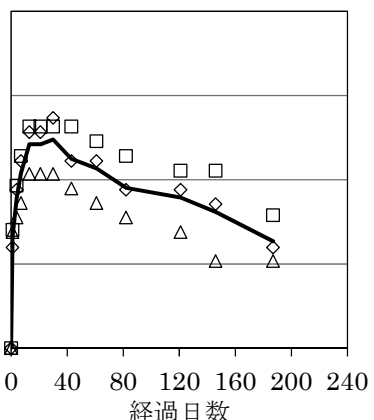

(c) $50^{\circ} \mathrm{C} 95 \% \mathrm{RH}$



養生条件 : $50^{\circ} \mathrm{C} 95 \% \mathrm{RH}$

図 2 熱伝導率の変化
ていることを確認する。バインダーについては、示差走査熱量測定 (DSC) 注 1)、ガラス繊維については走查型電子顕微鏡(SEM)による観 察と、エネルギー分散型 X 線分析(SEM-EDX) 注 2)を行う。

\section{2 測定結果}

\section{(1) 厚さの変化の測定}

図 1 は各条件における厚さ変化率の推移を示している。厚さ変化 率は、養生中の実測厚さを養生前の実測厚さで除した值である。相 対湿度が高いほど厚さの変化が速いことがわかる。また、 $50^{\circ} \mathrm{C}$ 95\%RH では、養生開始後 30 日目前後をピークとして、以降は厚さ が減少している。これはJIS A9521に準じ、150mm 角で質量が $100 \mathrm{~g}$ の加重板を試験体に載せて厚さを測定しているが、試験体の復元力 が低下するため、測定を行うたびに荷重板の負荷に耐えられず、沈 み込みが生じたことによる。なお、バインダーの退色は復元力の低 下が始まる以前から生じており、 $50^{\circ} \mathrm{C} 50 \% \mathrm{RH}$ の条件においても若 干の退色が見られた。

\section{(2) 熱伝導率測定}

図 2 は熱伝導率の推移を示している。養生によって試験体が膨張 するが、測定の都度乾燥させ、製品呼び厚さの $50 \mathrm{~mm}$ まで圧縮し、 測定している。図 1(c) と比較すると、復元力の低下を起こす状態に 至っても、呼び厚さにおける熱伝導率の増大は見られず、むしろわ ずかに小さくなる傾向にある。

\section{(3) バインダーの熱分析}

測定の結果を図 3 に示寸。常温保管の試料では $200 \sim 300^{\circ} \mathrm{C}$ の範 囲で吸熱反応が生じているが、 $50^{\circ} \mathrm{C} 95 \% \mathrm{RH}$ で養生したものや、才 ートクレーブ処理を行ったものは、吸熱反応が明瞭でなくなってい る。ここからわかることは、バインダーの中で吸熱反応を起こすも のがなくなっているということのみであるが、バインダーが何らか の変化を起こしていることは確かである。

\section{(4) ガラス繊維の表面元素分析}

写真 2 に、養生前後の電子顕微鏡画像を示す。養生によって䋊維 表面に異物が現れていることがわかる。この異物は、 $\mathrm{A} \sim \mathrm{C}$ 社いず れの試験体においても、養生開始後数日で繊維表面の凹凸として現 れ、しだいに大きくなった。

図 4 は 21 日間養生後の異物付近の EDX スペクトルの例であるが、 いずれのメーカーの試料でも $\mathrm{Ca}$ が多く検出された。なお、異物の ない部位では、ガラスの主成分である $\mathrm{Si} と \mathrm{O}$ が主に検出された。

また、分析試料作成時に、高温高湿養生によって、明らかにガラ

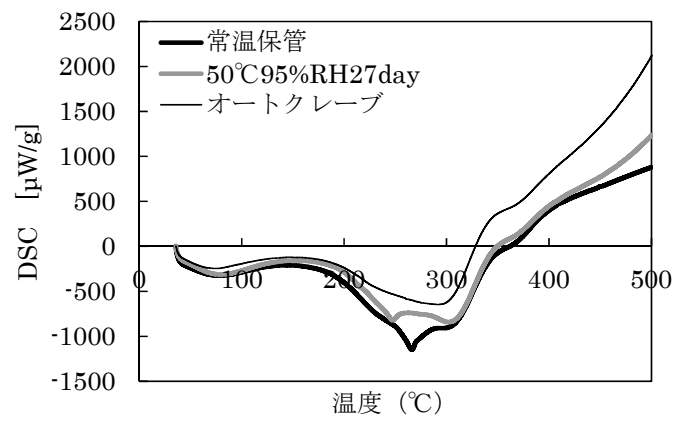

図 3 バインダーの DSC 測定結果

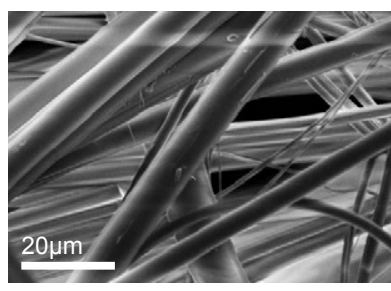

(a) 養生前

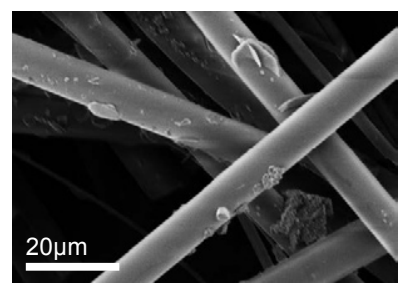

(b) $50^{\circ} \mathrm{C} 95 \%$ RH18 日間養生後
写真 2 養生前後の電子顕微鏡写真 (A 社ホワイトグラスウール)

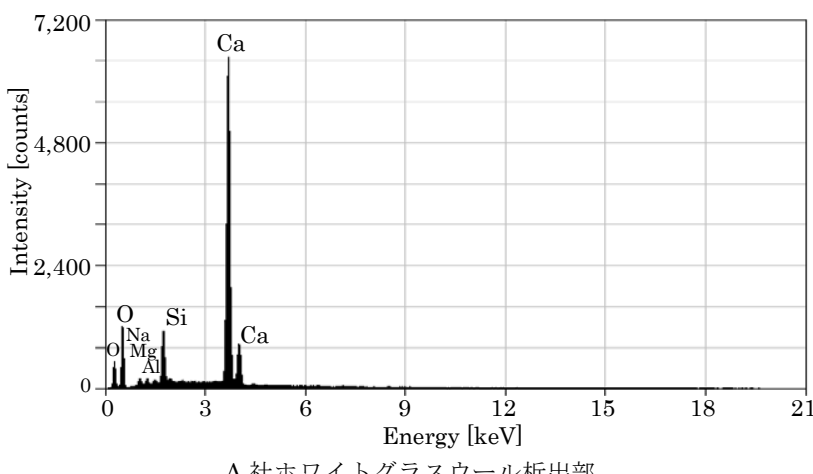

図 4 EDX スペクトル

ス繊維が折れやすくなることを確認した。

\section{3 考察}

フェルト状のグラスウールは通常圧縮梱包されているため、壁体 に施工した場合も、通気層側をシート状防風材で支持しているなど 厚さ方向の伸縮が完全に拘束されていない施工環境下では、100日 
以上の長期にわたって膨張を生じることが報告されている ${ }^{12)}$ 。ただ し、これまで膨張と環境条件の関係は明らかではなかったが、相対 湿度をパラメータとした促進試験により、相対湿度が膨張を加速さ せることがわかった。また、高温高湿養生をさらに継続すると、復 元力が低下した。これが「へたり」に相当すると考えられる。一方、 断熱性能に関しては、呼び厚さが確保されている限り、性能の低下 がないことがわかった。

次に、グラスウールの構成要素をそれぞれ単体で高温高湿養生し た結果、バインダーとガラス繊維ともに変化を生じることがわかっ た。高温高湿養生によってグラスウールが膨張するのは、バインダ 一の劣化によってガラス䋊維の拘束が解けることが原因として考え られる。また、ガラスは飽和水蒸気圧以下であっても表面への水の 吸着が生じ、表面の変質が生じることが知られており ${ }^{13) 、 S E M-E D X ~}$ で確認したように、水分による侵食を受けてガラス成分の一部が繊 維表面で結晶化し、ガラス繊維の機械強度の低下が引き起こされた と考えられる。復元力の低下やいわゆる「へたり」は、バインダー の劣化に加え、ガラス繊維の強度低下にも起因すると考えられる。

\section{4 現場採取グラスウールの調査}

\section{1 調査の目的と概要}

温湿度促進試験によって、グラスウールに膨張や復元力の低下が 生じることが確認されたが、実使用時の経年変化の内容との対応は 不明である。そこで、住宅の改修または解体の現場からグラウスー ルを採取し、各種分析を行う。

採取を行った住宅の建設年代は 1974 年から 1997 年で、10 棟か ら 17 種類を採取した。採取したグラスウールの一覧を表 2 に示す。 このうち、3 棟 10 種類(K1、K2、TA〜TF、KA、KB)については、 採取時に立会した。建設地は東京の 1 棟 1 種類を除き、北海道内で ある。使用部位は、外壁、小屋裏または床で、いずれもフェルト状 のグラスウールである。

採取したグラスウールは $350 \mathrm{~mm}$ 角に切り取り、サンプル数を 3 とする(量の少ない $\mathrm{KO}$ と $\mathrm{KB}$ は 2 サンプルとする)。各サンプルは、 表 1 の(1) と同じ方法で厚さを測定し、実測密度を算出する。

\section{2 調査結果}

\section{(1) 目視および顕微鏡観察}

採取したグラスウールの例を写真 3 に示す。外観上は、バインダ 一の退色によると考えられる色あせや、黒く変色した箇所が一部で 見られたほかは、概初健全に見えた。また、一部復元力が低下して いる感触はあったが、現地を確認した 3 棟においては、ずり落ちや 垂れ下がりなど、形状保持に支障をきたしているケースはなかった。

顕微鏡観察を行うと、写真 4 に示すように非黒色化部は概敉表面 が平滑だった。グラスウールによっては繊維表面に異物が確認され たものの、その量は温湿度促進試験で確認された異物と比べて少な かった。異物のうち促進試験同様に SEM-EDX で Ca が主成分とし て検出されたのは 17 種類中 2 種類(KO、DE)だった。SEM-EDX の 分析領域は数 $\mu \mathrm{m}$ のため、異物の量が少ない場合は異物中の成分を 検出できなかった可能性がある。

一方、黒色化した部分はいずれのサンプルも一様に表面に細かな 付着物が確認された。洗浄注 3)を行うと元のバインダーの色が現れ、 SEM でも洗浄後は平滑な表面が観察されたことから、変色はバイ
ンダーやガラス繊維の変化によるものではないと考えられる。また、 表面の付着物について、検查機関((株)衛生微生物研究センター)に分 析を依頼したところ、顕微鏡観察および培養の結果、変色原因はカ ビなどの微生物ではないとの見解が得られた。変色原因は、壁内気 流により空気中の塵埃が付着したものだと考えられる。

その他、性能変化要因とされている「微生物・昆虫／小動物」「薬 品・溶剤」の影響とみられる変化は確認されなかった。

\section{表 2 現場採取グラスウールの一覧}

\begin{tabular}{|c|c|c|c|c|c|c|c|c|}
\hline 記号 & メーカー & 色 & 使用部位 & 建設地 & 施工年 & $\begin{array}{l}\text { 通常/ } \\
\text { 高性能 }\end{array}$ & $\begin{array}{c}\text { 実測厚さ } \\
{[\mathrm{mm}]}\end{array}$ & $\begin{array}{l}\text { 実測密度 } \\
{\left[\mathrm{kg} / \mathrm{m}^{3}\right]}\end{array}$ \\
\hline K1 & A & 黄 & 外壁 & 旭川 & 1974年 & 通常 & 42.4 & 9.7 \\
\hline K2 & C（推定） & 赤 & 外壁 & 旭川 & 1974年 & 通常 & 40.4 & 11.7 \\
\hline $\mathrm{KO}$ & 不明 & 黄 & 外壁 & 旭川 & 1991年 & 高性能 & 79.0 & 15.1 \\
\hline DA & 不明 & 黄 & 外壁 & 札幌 & 1982年頃 & 通常 & 60.0 & 20.3 \\
\hline $\mathrm{DB}$ & 不明 & 黄 & 小屋裏 & 札幌 & 1982年頃 & 通常 & 36.3 & 12.8 \\
\hline DC & 不明 & 赤 & 小屋裏 & 札幌 & 1982年頃 & 通常 & 38.0 & 10.4 \\
\hline DD & 不明 & 黄 & 小屋裏 & 札幌 & 1982年頃 & 通常 & 93.7 & 10.7 \\
\hline $\mathrm{DE}$ & 不明 & 黄 & 小屋裏 & 札幌 & 1997年頃 & 通常 & 90.7 & 15.7 \\
\hline TA & D（推定） & 黄 & 和室床 & 旭川 & 1978年 & 通常 & 32.3 & 15.3 \\
\hline TB & $\mathrm{A}$ (推定） & 黄 & 2F外壁(南) & 旭川 & 1978年 & 通常 & 98.7 & 10.8 \\
\hline $\mathrm{TC}$ & $\mathrm{A}$ (推定) & 黄 & 寝室外壁 (東) & 旭川 & 1978年 & 通常 & 75.0 & 12.7 \\
\hline $\mathrm{TD}$ & 不明 & 赤 & 寝室外壁 (改修) & 旭川 & 1990年頃 & 高性能 & 101.0 & 14.2 \\
\hline TE & 不明 & 黄 & 間仕切り壁 & 旭川 & 1978年 & 通常 & 46.0 & 11.0 \\
\hline $\mathrm{TF}$ & 不明 & 黄 & 1F外壁 (北) & 旭川 & 1978年 & 通常 & 101.3 & 10.7 \\
\hline KA & 不明 & 黄 & 通気止め & 旭川 & 1981年 & 通常 & 93.0 & 16.2 \\
\hline KB & 不明 & 黄 & 床 & 旭川 & 1981年 & 通常 & 106.5 & 14.6 \\
\hline YA & B & 黄 & 外壁 & 東京 & 1994年 & 通常 & 38.3 & 12.1 \\
\hline
\end{tabular}

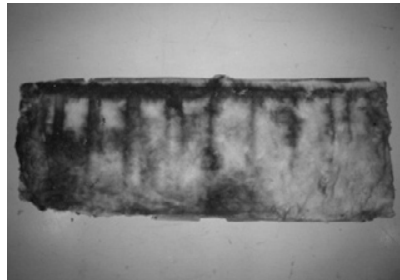

(a) K1

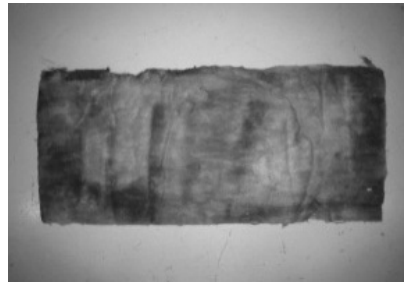

(b) K2
写真 3 現場採取材の例 (17 種類中の 2 種類)

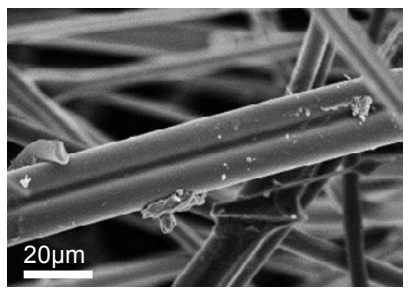

(a) 非黒色化部

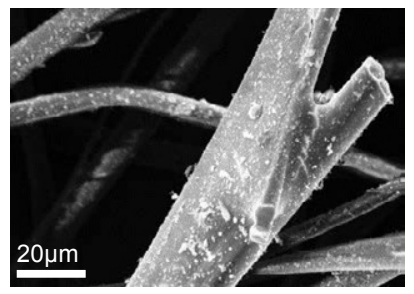

(b) 黒色化部
写真 4 試験体電子顕微鏡写真 (TF)

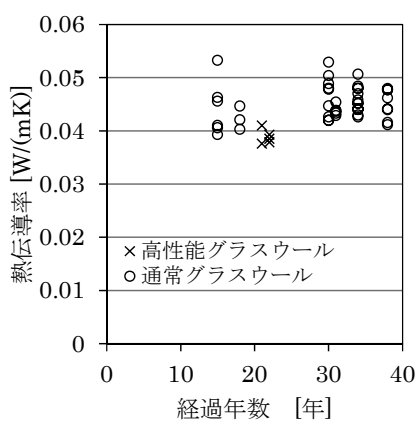

(a) 経過年数との関係



(b) 実測密度との関係
図 5 現場採取グラスウールの熱伝導率測定結果 


\section{(2) 熱伝導率の測定}

熱伝導率は、 17 種類、計 49 サンプルすべてを対象として、表 1 の(2)と同じ方法で測定した。ただし、測定時の厚さは JIS A9521 に準じ荷重板を用いて測定した実測厚さとした。図 5 に、経過年数 および実測密度と熱伝導率の関係を示す。高性能グラスウールかど うかは、施工年、熱伝導率および通気度による平均繊維径測定の結 果から判別した。熱伝導率は密度との相関が見られるが、使用年数 との明瞭な関係は見られない。

\section{3 考察}

現場採取グラスウールの調査においては、バインダーの退色や復 元力の低下、部分的な黒色化などが観察されたものの、現場を確認 した範囲では、断熱性能に影響を及ぼすと考えられる脱落、収縮な どの形状の変化は見られなかった。

熱伝導率については、製品の初期值や規格值との比較が難しく、 先の温湿度促進試験で熱伝導率にほとんど変化が生じなかった(図 2)ことから考えても、形状安定性を含めたグラスウールの長期性能 の評価指標として十分とは言えない。

したがって、促進試験と現場採取グラスウールの調査結果を結び 付け、グラスウールの長期性能を検証するためには、より定量的に 評価可能な別の方法を検討する必要がある。

\section{5 突き刺し試験}

\section{1 評価方法の要件}

評価方法の要件としては、経年変化の定量的な評価が可能である ことのほかに、促進試験や現場採取材の測定を行うため、同じ試験 体で繰り返し試験が可能なこと、不整形のサンプルでも試験可能な こと、測定に要する時間が比較的短いことなどが求められる。表 3 に各種評価方法での対応可否を示すが、既存評価方法でこれらの要 件をすべて満足する方法は見当たらない。一方、厚さの変化を測定 する過程において、針を突き刺す際の抵抗が、グラスウールの変化 とともに小さくなることが確認され、その抵抗力を測定することが、 本研究における評価手法として有用であると考えられた。そこで、 以下のように試験方法の検討を行った。

\section{2 試験方法の検討}

\section{(1) 圧縮力の測定方法}

日本電産シンポ製デジタルフォースゲージ FGP-0.2 にピアノ線 を垂直に取り付け、電動スタンドに設置する。試験状況を写真 5 に 示す。ピアノ線をグラスウール突き刺したときの抵抗は、フォース ゲージにより圧縮力として測定される。圧縮力は、一定速度でフォ ースゲージを下方に移動しながら、 0.1 秒間隔で 10 秒間継続測定を 行う。

\section{(2)ピアノ線の太さ}

通常入手できる直径 $0.3 \mathrm{~mm}$ および直径 $0.6 \mathrm{~mm}$ のピアノ線で試験 を行ったところ、直径 $0.6 \mathrm{~mm}$ ではグラスウール自体が圧縮されて ピアノ線が突き刺さらないことがあった。そのため、直径 $0.3 \mathrm{~mm}$ のピアノ線を採用することとする。

\section{(3) ピアノ線の先端形状}

写真 6 に示すように、ピアノ線カッターで切断したままのもの、 砥石で先端を平滑に処理したもの、円錐状に処理したものの 3 種類 について試験を行った。試験体は D 社 HG16K である。各条件 10

\section{表 3 評価方法の比較}

\begin{tabular}{|c|c|c|c|c|}
\hline & $\begin{array}{l}\text { 経年変化の } \\
\text { 定量的評価 }\end{array}$ & 繰り返し測定 & \begin{tabular}{|l} 
不整形サン \\
プル測定
\end{tabular} & $\begin{array}{l}\text { 測定に要す } \\
\text { る時間 }\end{array}$ \\
\hline 厚さ測定 & $\triangle$ & $\triangle$ & $x$ & 0 \\
\hline 熱伝導率測定 & $\triangle$ & 0 & $x$ & $\triangle$ \\
\hline DSC & $\triangle$ & $\bigcirc$ & $\bigcirc$ & $\triangle$ \\
\hline 顕微鏡観察 & $\triangle$ & 0 & O & $\triangle$ \\
\hline 引張、圧縮試験 & $\bigcirc$ & $x$ & $x$ & $\triangle$ \\
\hline $\begin{array}{l}\text { 突き刺し試験 } \\
\text { (本研究で提案 } \\
\text { する方法) }\end{array}$ & $\bigcirc$ & $\bigcirc$ & $\bigcirc$ & $\bigcirc$ \\
\hline
\end{tabular}

$\bigcirc:$ 可, $\triangle$ : 一部可, $\times$ : 不可



写真 5 突き刺し試験の状況



(a)切り放し

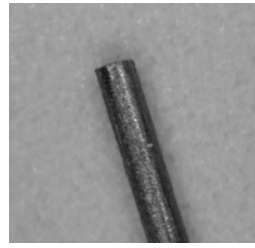

(b) 平滑処理

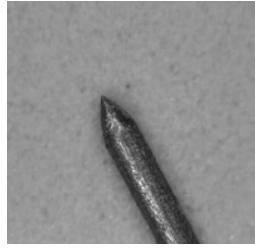

(c) 円錐処理

\section{写真 6 ピアノ線先端形状拡大写真}



(a) 切り放し

(b) 平滑処理

(c) 円錐処理

図 6 先端形状による圧縮力の違い(突き刺し速度 $200 \mathrm{~mm} / \mathrm{min}$ )

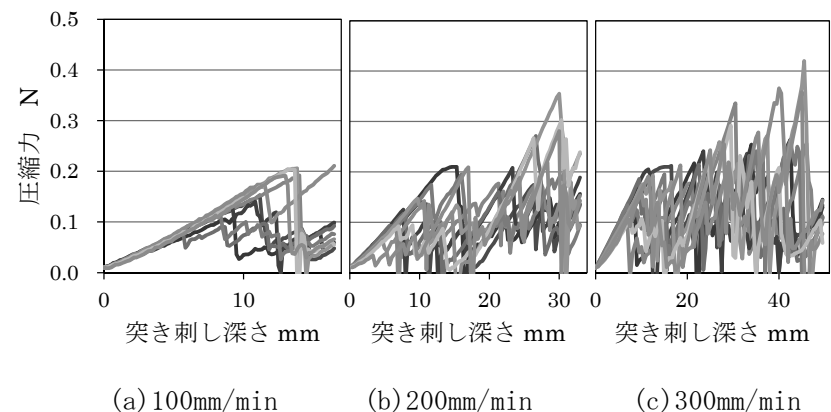

図 7 突き刺し速度による圧縮力の違い(針先端平滑処理) 
か所で突き刺しを行った結果は図 6 のとおりで、測定值のばらつき が少なく、先端処理形状の再現性が高い平滑処理を採用する。

\section{(4) 突き刺し速度}

突き刺し速度を $100 、 200 、 300 \mathrm{~mm} / \mathrm{min}$ の 3 段階に設定して比較 を行った。試験体は D 社 HG16K である。各条件 10 か所で突き刺 しを行った結果を図 7 に示す。 $100 \mathrm{~mm} / \mathrm{min}$ では、突き刺し行程が $16.7 \mathrm{~mm}$ であり、材料内での密度むらが大きいグラスウールを評価 するには、より行程を大きくとることが望ましい。一方、 $300 \mathrm{~mm} / \mathrm{min}$ とすると、突き刺し行程が $50 \mathrm{~mm}$ となり、薄い試験体 に対応できないため、突き刺し速度は $200 \mathrm{~mm} / \mathrm{min}$ とする。

\section{(5) 突き刺し試験力の定義}

試験結果にはガラス繊維の径、配向、密度が均一でないことに起 因するばらつきが生じるため、 1 仕様 1 条件につき 10 か所で突き刺 しを行う。また、突き刺しを行った箇所はマーキングし、次に突き 刺しを行う箇所とは $5 \mathrm{~mm}$ 以上の間隔を確保する。さらに、10 か所 それぞれで突き刺し中に測定される圧縮力の平均值を算出し、10 か 所の中央值を「突き刺し試験力」と定義する。なお湿潤状態にある 試験体は乾燥後に突き刺し試験を行う。以降では、この突き刺し試 験力を用いて評価を行う。

\section{3 促進試験体と現場採取グラスウールの比較 (1) 促進試験の突き刺し試験による評価}

5.2 で検討した方法を用い、各種グラスウールの促進試験におけ る突き刺し試験力の変化と、現場採取グラスウールの突き刺し試験 力を比較する。

図 8 に各種グラスウールを $75^{\circ} \mathrm{C} 95 \% \mathrm{RH}$ で養生を行い、突き刺し 試験力の変化を調べた結果を示す。グラフには各回 10 か所の突き 刺し試験力の最大・最小值と四分位点を表示している。グラスウー ルの密度が大きいほど突き刺し試験力も大きくなることと、いずれ も高温高湿養生により突き刺し試験力が低下寸ることがわかる。バ インダーの劣化とガラス䋊維強度の低下が、それぞれ突き刺し試験 力の低下に寄与する度合いは明確ではなく、各回の試験力にばらつ きもみられるが、中央值で評価することにより、同じ種類のグラス ウールであれば、突き刺し試験により性状の変化を定量的に把握で きると考えられる。

\section{(2) 現場採取グラスウールの突き刺し試験による評価}

図 9 に 17 種類の試験体における突き刺し試験結果を示す。図中 に点線で示したように、同じ住宅から採取したグラスウールは、メ 一カーや製品が異なっていても突き刺し試験力が比較的近い範囲に あった。また、小屋裏で使用されていたグラスウールは比較的大き な突き刺し試験力を有していた。一方、同程度の密度でも突き刺し 試験力は大きくばらついており、使用環境の差が表れていると考え られる。中には図 8 の初期值と比較して突き刺し試験力が小さく、 長期使用により突き刺し試験力が低下した可能性のあるグラスウー ルもあり、これらは実際に「へたり」を生じている感触があった。 このように、現場採取グラスウールについても、突き刺し試験を用 いて促進試験と同様の指標で評価でき、促進条件と実環境における 比較も可能になると考えられる。

\section{(3) 断熱性能との関係および既往の測定法との比較}

3.2(2)で述べたように、復元力の低下によってグラスウール自体 の熱伝導率が大きくなることはない。グラスウールの変化が断熱性
能の低下を起こすとすれば、復元力の低下によって形状安定性に支 障をきたし、実際にずり落ちや垂れ下がりが生じるに至った場合で ある。そのような状況が生じうるのは、図 1(c)の場合で言えば、少 なくとも載荷により厚さが減少に転じる 30 日目以降であると考え られる。

ここで問題とする復元力は、突き刺し試験力と同様にガラス䋊維 強度やバインダーの付着力が関係していることから、突き刺し試験 力と復元力は互いに関連付けられると考えられる。そこで次の 6 で は、突き刺し試験力と復元力を関連付けて経年変化の予測を試みる。 なお、グラスウールメーカーでは、従来から製品管理の一環とし て、圧縮試験や引張試験を実施している。これらの既往の試験方法 により、高温高湿養生によるグラスウールの変化を確認したところ、 突き刺し試験と同様、試験力に低下が生じた注4)。圧縮試験や引張試 験もまた繊維強度やバインダーの付着力に関わることから、結果は 突き刺し試験と関連性があると考えられるが、長期の評価において は、同じ試験体で繰り返し試験ができることが望ましいため、新た な試験方法である突き刺し試験を用いることとする。



$\mathrm{GW}$ : 通常グラスウール、 $\mathrm{HG}$ ：高性能グラスウール、数字は実測密度 $\left(\mathrm{kg} / \mathrm{m}^{3}\right)$ 盖生条件： $75^{\circ} \mathrm{C} 95 \% \mathrm{RH}$

各試験体とも左から養生前の初期值、養生後 4 日目、10 日目、21 日目の試 験結果を示す（一部仕様では 21 日目の試験を実施していない)

図 8 各種グラスウールの突き刺し試験カの変化

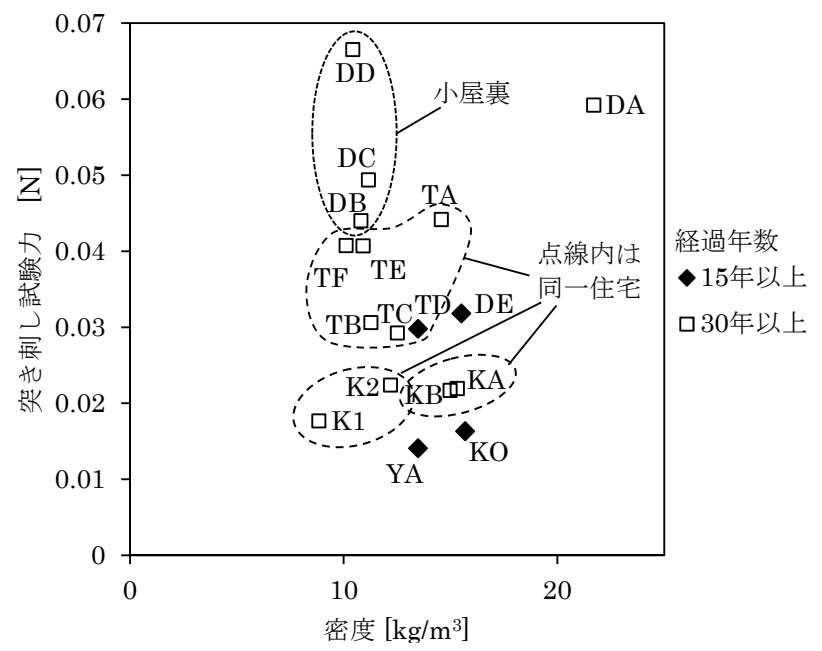

図 9 現場採取グラスウールの突き刺し試験結果 
6 寿命予測モデルによる長期性状変化の予測

\section{1 温湿度促進試験における突き刺し試験力の変化 (1) 試験方法}

これまでの検証により、促進試験体と長期使用した現場採取グラ スウールの両方で、突き刺し試験力の低下が確認された。また、突 き刺し試験力の低下には温度および相対湿度が関係していると考え られる。そこで、温度および相対湿度をパラメータとして促進試験 を行い、経年変化の予測を試みる。

促進試験の条件は、寿命予測モデルの適用を想定して、温度を $25^{\circ} \mathrm{C} 、 37.5^{\circ} \mathrm{C} 、 50^{\circ} \mathrm{C} 、 75^{\circ} \mathrm{C} の 4$ 水準、相対湿度を $75 \% 、 85 \% 、 95 \%$ の 3 水準とする。

試験体は、 $\mathrm{A}$ 社、 $\mathrm{B}$ 社、 $\mathrm{C}$ 社の HG16K、呼び厚さ $100 \mathrm{~mm}$ の製 品とし、 $200 \mathrm{~mm}$ 角で切り出す。評価方法は突き刺し試験とする。

\section{(2) 試験結果}

試験の結果を図 10 に示す。また、同図には式(1)による試験結果 の回帰曲線を併せて示す。

$$
y=a \cdot \ln (x)+b
$$

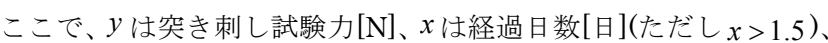
$a$ と $b$ は断熱材の仕様と養生条件ごとに決まる定数を表す。

温度、相対湿度ともに、突き刺し試験力低下の速度と明瞭な関係 があることがわかる。なお C 社の HG16K は、ガラス繊維の耐久性 に関係があるとされる $\mathrm{B}_{2} \mathrm{O}_{3}$ を添加していない。このため、特に高 温条件で他の製品よりも突き刺し試験力の低下が早く進んでいると 考えられる。

\section{2 寿命予測モデルの検討}

温度を含む複数の加速因子を用いた促進試験により工業製品の寿 命を予測するためには、次式のアイリングモデルが使用される ${ }^{14115)}$

$$
L=\alpha \cdot \exp \left(E_{a} / k T\right) \cdot f(S)
$$

ここで、 $L$ はある状態に至るまでの時間、 $\alpha$ は定数、 $E_{a}$ は活性化

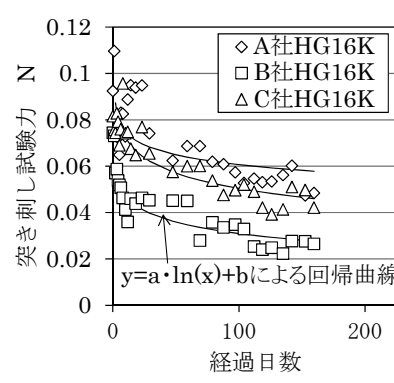

(a) $25^{\circ} \mathrm{C} 95 \% \mathrm{RH}$

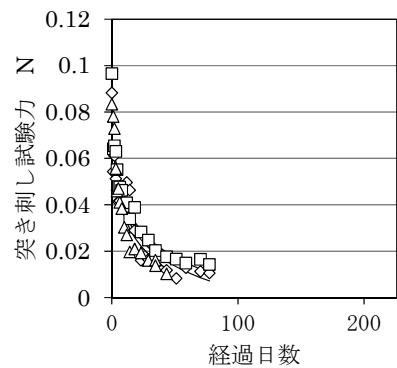

(e) $50^{\circ} \mathrm{C} 95 \% \mathrm{RH}$

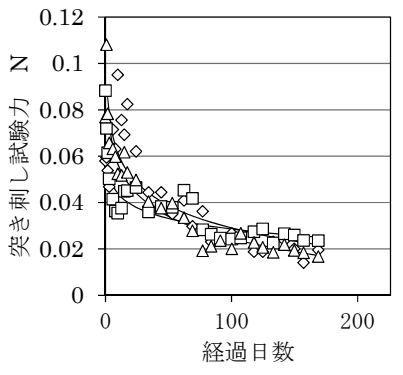

(b) $37.5^{\circ} \mathrm{C} 95 \% \mathrm{RH}$

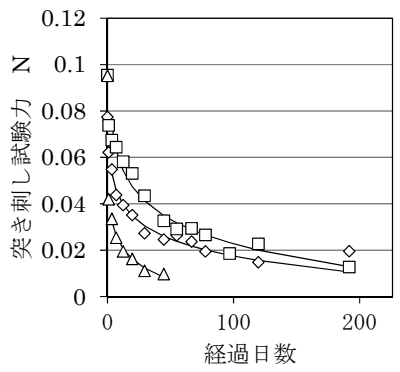

(f) $75^{\circ} \mathrm{C} 75 \% \mathrm{RH}$

エネルギー $[\mathrm{eV}] 、 k$ はボルツマン定数 $[\mathrm{eV} / \mathrm{K}] 、 T$ は絶対温度 $[\mathrm{K}] 、 S$ は 温度以外のストレス因子を表す。

温度以外のストレスを相対湿度としたときの関数モデルはいくつ か提案されているが、ここでは $f(S)=\exp (\beta / R H)$ を採用すると、式 (2)は次のようになる。

$$
L=\alpha \cdot \exp \left(E_{a} / k T\right) \cdot \exp (\beta / R H)
$$

ここで、 $\beta$ は定数、 $R H$ は相対湿度[\%]を表す。

さらに両辺の対数をとると次式となる。

$$
\ln L=\ln \alpha+E_{a} / k T+\beta / R H
$$

よって、 $\ln L$ は $1 / T$ と $1 / R H$ に関寸る 1 次式で表される。したが って、 $T$ と $R H$ をパラメータとする促進試験から、重回帰により断 熱材の種類ごとに定まる定数 $\ln \alpha 、 E_{a} / k 、 \beta$ を求めることができる。

ここで、指標となる突き刺し試験力であるが、図 1(c)によると、 荷重板の負荷に耐えられずに厚さが減少に転ずるのは 30 日目以降 である。一方、同条件で突き刺し試験を行った図 10(e)を見ると、 30 日目における突き刺し試験力はメーカーによる違いはあるが、 $0.02 \mathrm{~N}$ 程度である。したがって、0.02N の突き刺し試験力を有して いれば、形状を保持するための機械強度は、まだ十分に余裕がある 状態である考えられる。よって、ここでは例として、突き刺し試験 力が $0.02 \mathrm{~N}$ まで低下寸るまでの日数を指標として、各係数を求める。

$L$ は式(1)で $\mathrm{y}=0.02$ としたときの $x$ とする。なお期間中に突き刺 し試験力が $0.02 \mathrm{~N}$ まで低下していない一部の条件では、式(1)による 外挿により $L$ を求めるが、 $25^{\circ} \mathrm{C} 95 \% \mathrm{RH}$ のうち $\mathrm{A}$ 社品、 $\mathrm{C}$ 社品、 $50^{\circ} \mathrm{C}$ $75 \% \mathrm{RH}$ のうち $\mathrm{A}$ 社品は十分なデータが得られていないため除外す る。

表 4 に重回帰により求めた $\ln \alpha 、 E_{a} / k 、 \beta$ の值を示す。これらの 各係数を用いて、横軸を $E_{a} / k T+\beta / R H$ 、縦軸を $L$ の対数とした試 験結果のプロットと、式(4)による回帰直線を図 11 に示す。実験結 果は、概ね回帰直線上に分布している。



(c) $50^{\circ} \mathrm{C} 75 \% \mathrm{RH}$



(g) $75^{\circ} \mathrm{C} 85 \% \mathrm{RH}$

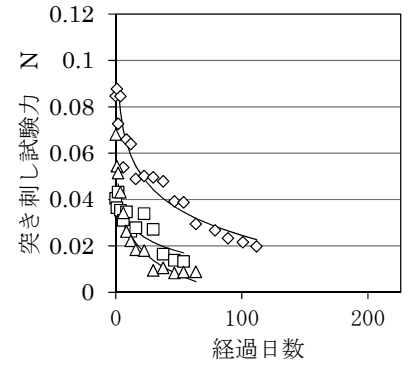

(d) $50^{\circ} \mathrm{C} 85 \% \mathrm{RH}$

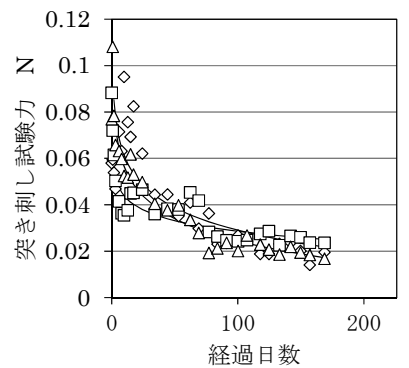

(h) $75^{\circ} \mathrm{C} 95 \% \mathrm{RH}$

図 10 温湿度促進試験の結果 
この直線関係が、より低温、低湿の条件でも成り立つとの仮定の もとに、外挿によって実際に製品が使用される環境での寿命を予測 するのが、実用的に行われている寿命予測の方法である。ここでも、 同様の仮定のもと、グラスウールの経年変化の予測を試みる。

\section{3 経年変化の予測}

\section{3. 1 温湿度一定の場合}

表 5 に、例として 3 つの温湿度条件において、突き刺し試験力が $0.02 \mathrm{~N}$ に低下寸るまでの年数求めた結果を示寸。表 5 の温湿度条件 は、年間を通じた壁体内の温湿度としては高めの值であるが、常温 でも相対湿度が高い状態が続けば、建物の使用期間中にグラスウー ルの復元力低下などの経年変化が相当進む可能性のあることが示さ れた。

\section{3.2 温湿度履歴を考慮した場合}

\section{(1) 計算方法}

防湿条件による経年変化の違いを確認するため、気象デー夕を用 いて壁体内部の温湿度履歴を計算し、グラスウールの経年変化の予 測を行う。

計算を行う壁体の構成を図 12 に示寸。室内側の透湿抵抗は同図 中に示す (1)〜 (3)の 3 条件とする。計算地点とした札幌市の場合、 (1) の防湿フィルム B 種相当が、通常使用されている防湿材である。各 材料の物性值は定数とする。外気条件は拡張アメダス気象データの 札幌標準年、計算方位は北面とする。計算プログラムには非定常熱・ 湿気計算システム H\&M(ver.2.3.1)を用い、一般部に注目した一次元 解析を行う。その他室内の条件などは文献 16)により、計算開始後 3 年目のデータが毎年繰り返されるものとする。経年変化の度合いは、 突き刺し試験力の変化により表すこととし、式(4)により計算時間間 隔ごとの突き刺し試験力の減少分を計算するが、 $\ln \alpha 、 E_{a} / k 、 \beta$ の 各定数は、突き刺し試験力の低下とともに変化する。そこで、突き 刺し試験力が $0.01 \mathrm{~N}$ 低下寸るごとに各定数の值を計算し直し、その とき保持している突き刺し試験力に応じた各定数の值を用いて計算 を行う。初期值は各社とも $0.06 \mathrm{~N}$ とする。

表 4 各断熱材の $\ln \alpha 、 E_{a} / k 、 \beta$

\begin{tabular}{c|ccc}
\hline & $\mathrm{A}$ 社HG16K & B 社HG16K & C 社HG16K \\
\hline $\ln \alpha$ & -41.0 & -35.0 & -42.8 \\
$\mathrm{E}_{\mathrm{a}} / \mathrm{k}$ & 10,630 & 9,318 & 12,309 \\
$B$ & 1,116 & 942 & 729 \\
\hline
\end{tabular}



$\diamond \mathrm{A}$ 社HG16K $\square B$ 社HG16K $\Delta \mathrm{C}$ 社HG16K

図 11 式(4)に基づく試験結果のプロットと回帰直線

\section{(2) 計算結果}

壁体内の温湿度の計算結果を図 13(a)(b)に示す。室内側に(1)防湿 フィルム B 種相当の透湿抵抗を与えた場合は、グラスウールの室外 側境界の相対湿度は年間を通じて 40\%〜 50\%で推移する。(2)付属防 湿層相当の場合は、 $65 \%$ ～85\%程度となる。一方、(3)有孔 $\mathrm{PE}$ 相当 の場合は冬季に長期間結露を生ずることとなる。

このとき、突き刺し試験力の 30 年間の変化を試算した結果を図 13(c)に示す。通常使用されている(1)防湿フィルム B 種相当の場合、 $\mathrm{A}$ 社品および $\mathrm{B}$ 社品は計算上変化せず、 $\mathrm{C}$ 社品もわずかな低下にと どまっている。(2)付属防湿層相当の場合は各社とも突き刺し試験力 が低下する傾向が現れる。(3)有孔 PE 相当の場合は各社とも 5 年程 度で $0.02 \mathrm{~N}$ 以下まで低下寸るという結果になった。

\section{表 5 任意温湿度における $L$ の計算例}

\begin{tabular}{|c|c|c|c|c|c|c|c|}
\hline \multirow{2}{*}{$\begin{array}{l}\text { 温度 } \\
{\left[{ }^{\circ} \mathrm{C}\right]}\end{array}$} & \multirow{2}{*}{\begin{tabular}{|c|} 
相対湿度 \\
{$[\%]$}
\end{tabular}} & \multicolumn{3}{|c|}{$\mathrm{E}_{\mathrm{a}} / \mathrm{kT}+\mathrm{B} / \mathrm{RH}$} & \multicolumn{3}{|c|}{$\mathrm{L}$ [年] } \\
\hline & & $\mathrm{A}$ 社HG16K & B社HG16K & C社HG16K & $\mathrm{A}$ 社HG16K & B社HG16K & $\mathrm{C}$ 社HG16K \\
\hline 25 & 60 & 54.2 & 46.9 & 53.4 & 1627 & 427 & 110 \\
\hline 25 & 95 & 47.4 & 41.2 & 49.0 & 1.7 & 1.3 & 1.3 \\
\hline 30 & 70 & 51.0 & 44.2 & 51.0 & 63 & 27 & 10 \\
\hline
\end{tabular}

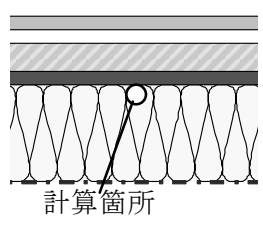

壁体構成

·外装材

・通気層 $18 \mathrm{~mm}$

- XPS2b 30mm

- 合板 $12 \mathrm{~mm}$

(20.0015(有孔 $\mathrm{PE}$ 相当)

G16K 105mm 計算地点 札幌市

その他の計算条件は文献 16)による。

図 12 計算を行う壁体の構成



(a) 温度

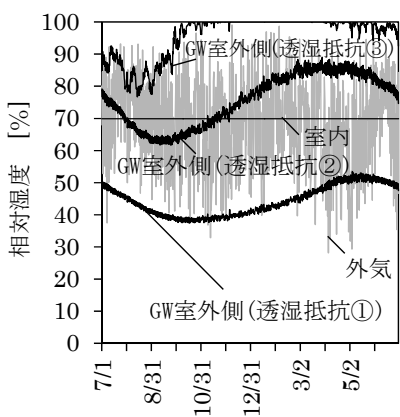

(b) 相対湿度

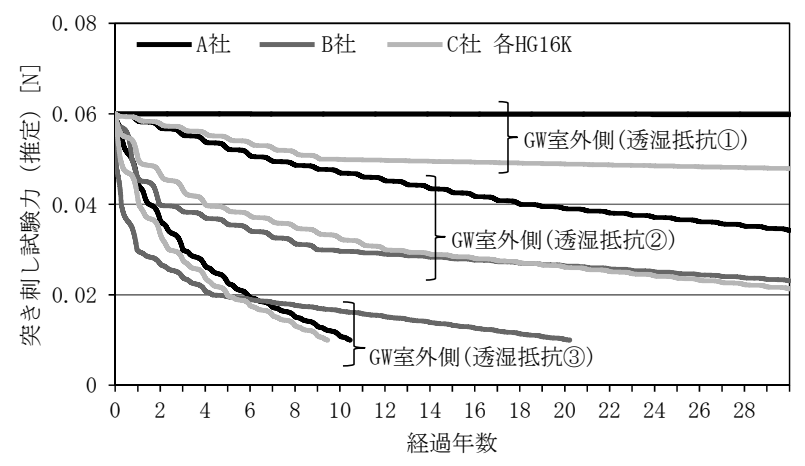

(c) 突き刺し試験力の推定值 (C 社 HG16K)

図 13 計算結果 


\section{7 まとめ}

本研究では、促進試験および長期使用した断熱材の実態調查によ り、グラスウールの長期性状変化を検証した。得られた主な知見は 次のとおりである。

(1)グラスウールの経年変化に影響を及ぼす要因として熱、水分を取 り上げ、促進試験による検証を行った。その結果、高温高湿の条 件下で、バインダーの劣化とガラス繊維の強度低下が生じ、厚さ の増大と復元力の低下(いわゆる「へたり」)をもたらすことがわ かった。

(2)上記のような変化が生じても、呼び厚さにおける熱伝導率は大き くならない(断熱性能は低下しない)ことがわかった。

(3)現場採取調査においても、促進試験と同様の色あせや復元力が低 下していると考えられる状況が一部で確認された。しかし、形状 保持に支障をきたしているような事例は確認されなかった。

(4)グラスウールの経年変化の新たな評価方法として、定量的な評価 や繰り返し測定が可能であること、不整形なサンプルの測定にも 適用可能であり、測定に要する時間も比較的短いなどの長所を持 つ突き刺し試験を提案した。

(5)温度および湿度をパラメータとした促進試験を実施し、促進試験 で得られた温湿度と変化の速度が、より低温、低湿の条件でも成 り立つとの仮定のもとで、実用環境での経年変化の予測を試みた。

グラスウールの長期性能を保つには、これまでも言われているよ うに、防湿層や通気層などによる壁内乾燥措置を講じ、水平部位に ついては長期的な垂れ下がりを防止する措置を講ずることが重要で ある。

なお本研究は、硝子繊維協会と北方建築総合研究所の共同研究と

して実施した。

\section{参考文献}

1）独立行政法人新エネルギー・産業技術総合研究機構 : 平成 19 年度断熱 材の長期断熱性能評価に関する標準化調査成果報告書, 2008.3

2）近藤靖史，長澤康弘，藤本哲夫，田坂太一：発泡プラスチック系断熱材 の長期断熱性能変化の測定および数值解析, 日本建築学会環境系論文集, 第 634 号，pp.1361-1368，2008.12

3）近藤靖史, 岩前篤, 長澤康弘, 藤本哲夫, 菊地裕介, 田坂太一：断熱材 の性能変化要因の検討と振動による断熱性能変化の実験 建築用断熱 材の長期断熱性能変化に関寸る研究, その 1 , 日本建築学会環境系論文 集，第 643 号, pp.1049-1057, 2009.9

4）近藤靖史，岩前篤，長澤康弘，藤本哲夫，菊地裕介，田坂太一：水分に よる断熱材の断熱性能変化に関する実験 建築用断熱材の長期断熱性 能変化に関する研究, その 2 , 日本建築学会環境系論文集, 第 649 号, pp.261-269, 2010.3

5）日本建築学会 : 建築工事標準仕様書 - 同解説 JASS24 断熱工事, 日本建 築学会, 2013.2

6) ISO 18393-1 : Thermal insulation products - Determination of ageing by settlement - Part 1: Blown loose-fill insulation for ventilated attics, 2012

7）検証壁の中のグラスウール，硝子䋊維協会，2008.5

8) 長尾崇史，橋本弥古武，近藤潤 : 断熱材の耐久性に関寸る基礎的研究(そ の 1）事例紹介および耐久性検証に関する考察，日本建築学会大会学術 講演梗概集 A-1，pp371-372，2008.9

9）二川智吏，李時桓，趙旺熙，手塚純一，加藤信介：既存住宅の断熱性能 診断に関する技術検証(その 1) 実建物における断熱材の長期断熱性評 価方法に関する検証, 日本建築学会大会学術講演梗概集 D-2, pp.103-104, 2009.8

10） JIS A9521：住宅用人造鉱物繊維断熱材，2011

11） JIS A1412-2 : 熱絶縁材の熱抵抗及び熱伝導率の測定方法－第 2 部 : 熱 流計法(HFM 法), 1999

12）鈴木大隆，廣田誠一，福島明：シート状防風材を用いた木造断熱壁にお ける通気層空隙の確保に関する実験的研究，日本建築学会計画系論文集， 第 480 号，pp. 123-128，1996.2

13）土橋正二 : ガラス表面の物理化学, 講談社, 1979.5

14）半導体デバイスの加速寿命試験運用ガイドライン，電子情報技術産業協 会, 2007.3

15）石山央樹，腰原幹雄，中野一郎：アイリングモデルを利用した木造住宅 における鉄釷の寿命予測，日本建築学会技術報告集，第 16 巻第 33 号, pp.453-456, 2010.6

16）計算の結果による温熱環境(結露の発生を防止する対策)に関する試験力 イドライン，住宅性能評価・表示協会, 2009.11

17）立松宏一，廣田誠一，鈴木大隆，井上幹生，松村茂，松岡修，布井洋二, 斎藤貴己，鵜澤孝夫 : グラスウールの長期断熱性能に関する研究，日本 建築学会大会学術講演梗概集環境工学 II , pp.97-98, 2013.8

注 1）熱分析手法の一つで、試料を一定の昇温速度で加熱したときの熱の出入 りを計測することにより、相転移や化学反応など熱の出入りを伴う現象 を、温度と関連付けて把握できる。

注 2) SEM-EDS とも呼ばれる。走査型電子顕微鏡における試料への電子線照 射により発生する特性 X 線のエネルギーは元素に固有であり、その強度 (X 線光量子の数) が元素濃度に比例するので、 $\mathrm{X}$ 線のエネルギースペク トルから表面付近に存在する元素の定性定量分析ができる。

注 3）界面活性剂を主成分とする中性の台所用合成洗剂を添加した水中に試 料を浸し、 $50^{\circ} \mathrm{C}$ で 1 時間放置した後、水道水ですすぎ、乾燥させた。

注 4）圧縮および引張試験による、高温高湿養生前後のグラスウールの変化を 付図 1 に示す。



試験体：D 社 HG16K50mm サイズ : $150 \times 150 \times 50[\mathrm{~mm}]$ サンプル数 : 8

圧縮板を $10 \mathrm{~mm} / \mathrm{min}$ で下降させ

厚さ $25 \mathrm{~mm} の$ のきの荷重を測定

(a)圧縮試験 付図 1 圧縮試験および引張試験の結果



\section{試験体：D社 HG16K50mm サイズ : $100 \times 150 \times 50[\mathrm{~mm}]$ サンプル数 : 4 破断するまでの最大荷重を測定}

(b)引張試験 


\title{
INFLUENCE OF TEMPERATURE AND MOISTURE ON AGING OF GLASS WOOL
}

\author{
Koichi TATEMATSU* ${ }^{*}$, Tomohito HIROTA** , Hirotaka SUZUKI***, \\ Madoka TANIGUCHI***, Yoji NUNOI**** and Takao UZAWA***** \\ "Hokkaido Research Organization Northern Regional Building Research Institute, M. Eng. \\ ** Hokkaido Research Organization Northern Regional Building Research Institute \\ *** Hokkaido Research Organization Northern Regional Building Research Institute, Dr. Eng. \\ **** ASAHI FIBER GLASS Co., Ltd. \\ $* * * * *$ Glass Fiber Association of Japan
}

The promotion of the long-term use of high-quality building stock is a very important subject. Such a stock system is essential for undertaking the measures required to maintain the performance of a building, such as predicting the long-term changes in the properties of various building materials and removing the causes of such changes.

Previous studies have noted the long-term performance of plastic insulation foams, because gas substitution may cause changes in their thermal conductivities over time. On the other hand, with fiber insulation, validation is only being carried out in relation to changes in the performance factors of moisture and vibration. There is a growing need for thermal insulation with long-term performance. Therefore, there is a need to verify how time and other factors affect fiber insulation.

This study had the goal of extending our knowledge of the aging of glass wool through a survey of the changes in this insulation with long-term use, along with an acceleration test. First, the changes in glass wool were tested using accelerated temperature and humidity factors. Second, we collected glass wool from an old house, and compared its property changes with the results of the accelerated test. Third, we prepared a new method for verifying a property change. Finally, we attempted to predict the aging of glass wool by applying the life prediction model to the accelerated test. We obtained the following results.

(1) We focused on heat and moisture as the factors affecting the aging of glass wool, and verified these change using an accelerated test. As a result, it was found that under conditions of high temperature and high humidity, the strength of the glass fiber decreased and the binder deteriorated, which caused a decrease in the restoring force and an increase in the thickness.

(2) It was found that, in spite of these changes, the thermal conductivity at the nominal thickness had not increased. In other words, the heat insulating performance had not degraded.

(3) We developed a piercing test for an aging evaluation of glass wool. This test method enables quantitative evaluations, repeated measurements, the measurement of irregular samples, and relatively quick measurements.

(4) In the glass wool taken from old houses, a decrease in the piercing strength and fading similar to that seen in the accelerated test were observed. However, no problems with shape retention were observed.

(5) We conducted an accelerated test using temperature and humidity factors. Then, we attempted to predict the aging on the assumption that the relationship describing the changes with temperature and humidity in the accelerated test was also valid at lower temperature and humidity values.

This study was supported by a collaborative study between the Hokkaido Research Organization Northern Regional Building Research Institute and the Glass Fiber Association of Japan. 